RASĀYAN J. Chem.

Vol. 14 | No. 2 |665-671| April - June | 2021

ISSN: 0974-1496 | e-ISSN: 0976-0083 | CODEN: RJCABP

http://www.rasayanjournal.com

http://www.rasayanjournal.co.in

\title{
NOVEL RP-HPLC METHOD DEVELOPMENT AND VALIDATION OF TAMSULOSIN HCI AND DUTASTERIDE IN TABLETS BY RATIO'S METHOD
}

\author{
Kudupudi Chandrasekhar* and A. Manikandan \\ Department of Science \& Humanities, Bharath Institute of Higher Education and Research, \\ Selaiyur, Chennai, Tamilnadu-600073, India \\ Corresponding Author: kudupudichandra@gmail.com
}

\begin{abstract}
A novel simple selective, precise and accurate RP-HPLC method were developed for the simultaneous estimation by ratio's method of Tamsulosin $\mathrm{HCl}$ and Dutasteride in the combined formulation. The drugs were estimated for the ratio's of the peak areas for Tamsulosin $\mathrm{HCl}$, Dutasteride and the internal standard. The internal standard selected was propylparaben. The drugs and internal standard were separated on Kromasil C18 $(250 \times 4.6,5 \mu)$ with a reverse phase isocratic elution. A mixed phosphate buffer 35 volumes and acetonitrile 65 volumes were used as a mobile phase. the flow rate was $1.0 \mathrm{~mL} / \mathrm{min} .225 \mathrm{~nm}$ was the detection wavelength. The retention times were $2.804 \mathrm{~min}$ for Tamsulosin $\mathrm{HCl}, 4.371 \mathrm{~min}$ for internal standard(propylparaben) and $12.914 \mathrm{~min}$ for Dutasteride. The linearity ranges for Tamsulosin $\mathrm{HCl}$ and Dutasteride were 20.00 to 60.00 and 25 to $75 \mathrm{mcg} / \mathrm{ml}$ respectively with a correlation coefficient of 0.999 for both. The proposed ratio's method validated statistically concerning system suitability, specificity, linearity, precision, accuracy, range, robustness and ruggedness. The method was accurate, linear, precise, specific, selective and rapid suitable for the quantitative estimation of Tamsulosin $\mathrm{HCl}$ and Dutasteride by ratio's method.
\end{abstract}

Keywords: Ratio's Method, Tamsulosin, Dutasteride, Internal Standard, Tablets, RP-HPLC.

RASĀYAN J. Chem., Vol. 14, No.2, 2021

\section{INTRODUCTION}

Tamsulosin $\mathrm{HCl}$ chemically Benzenesulfonamide, 5-[2-[[2-(2-ethoxyphenoxy)ethyl] amino]propyl]-2methoxy-, monohydrochloride, Dutasteride chemically $(5 \alpha, 17 \beta)-\mathrm{N}-[2,5$-Bis(trifluoromethyl)phenyl]-3oxo-4-azaan-drost-1-ene-17-carboxamide. Tamsulosin $\mathrm{HCl}$ and Dutasteride are official in Indian, the United States and European Pharmacopoeia. But the combination of Tamsulosin $\mathrm{HCl}$ and Dutasteride is not official in any one of the pharmacopoeia. Tamsulosin $\mathrm{HCl}$ and Dutasteride combined formulation is used to treat the symptoms of an enlarged prostate gland in men, which is also called benign prostatic hyperplasia (BPH). The tablet combination dosage form in the ratio of 0.4:0.5 mg Tamsulosin $\mathrm{HCl}$ and Dutasteride respectively. The average weight of the tablet is about $202 \mathrm{mg}$. Many formulations are available with many trade names. Many methods have been reported for this combination by HPLC ${ }^{4-12}$, from literature reveals no internal standard method was reported to estimate the combination of Tamsulosin $\mathrm{HCl}$ and Dutasteride. So the proposed ratio's method simultaneously estimates the ratio of Tamsulosin $\mathrm{HCl}$ peak area to the internal standard (propyl paraben) peak area and the ratio of Dutasteride peak area to the internal standard (propyl paraben) peak area in a tablet formulation to correctly estimates the loss of analyte during the sample preparation.

\section{Instrumentation}

\section{EXPERIMENTAL}

The separation was carried out on Shimadzu HPLC system with quaternary gradient and UV and 20MP PDA detectors, LC solutions software and Kromasil C18 (250mmx4.6mm, $5 \mu \mathrm{m})$ column.

\section{Chemicals and Reagents}

The working standards of Tamsulosin $\mathrm{HCl}$ and Dutasteride were provided as gift samples from Bio-Leo Analytical Labs., Hyderabad. The marketed formulation was purchased from the local market. Propyl

Rasayan J. Chem., 14(2), 665-671(2021)

http://dx.doi.org/10.31788/ RJC.2021.1425740 
RASĀYAN J. Chem.

Vol. 14 | No. 2 |665-671| April - June | 2021

paraben from sigma. Potassium dihydrogen orthophosphate, DiPotassium dihydrogen orthophosphate Water and Acetonitrile of HPLC grade from Rankem.

\section{HPLC Conditions}

The mobile phase consisting of mixed phosphate buffer and acetonitrile in the ratio 35:65 was filtered through $0.45 \mu \mathrm{m}$ PVDF membrane filter before use, degassed and pumped through the column at a flow rate of $1.0 \mathrm{~mL} / \mathrm{min}$. The column was maintained at $40^{\circ} \mathrm{C}$ temperature. The elution was monitored at $225 \mathrm{~nm}$ and the run time was $20 \mathrm{~min}$. The injection volume was $10 \mu \mathrm{L}$. the column was equilibrated for about 30 min before injection of the drug solutions with the mobile phase.

\section{Preparation of Mixed Phosphate Buffer}

Dissolve $0.525 \mathrm{~g}$ of DiPotassium hydrogen orthophosphate and $2.67 \mathrm{~g}$ of Potassium dihydrogen orthophosphate in $1000 \mathrm{ml}$ of water.

\section{Preparation of Diluent}

Acetonitrile and water in the ratio 3:7.

\section{Preparation of Internal Standard Stock Solution}

Accurately transferred $100 \mathrm{mg}$ of propyl paraben into $100 \mathrm{ml}$ volumetric flask dissolve and diluted to volume with diluent.

\section{Preparation of Standard Stock Solutions}

Tamsulosin HCl

Weighed Accurately $4.00 \mathrm{mg}$ transferred into $10 \mathrm{~mL}$ of volumetric flask dissolve and diluted to volume with diluent and sonicate for $10 \mathrm{~min}$.

\section{Dutasteride}

Weighed Accurately $5.00 \mathrm{mg}$ transferred into $10 \mathrm{~mL}$ of volumetric flask dissolve and diluted to volume with diluent and sonicate for $10 \mathrm{~min}$.

\section{Preparation of Standard Solution}

Accurately transferred $1 \mathrm{ml}$ each of Tamsulosin $\mathrm{HCl}$, Dutasteride and internal standard stock solutions into $10 \mathrm{ml}$ volumetric flask dissolve and diluted to volume with diluent.

\section{Preparation of Sample Solution}

Accurately transferred sample powder equivalent to $0.8 \mathrm{mg}$ of Tamsulosin $\mathrm{HCl}$ and $1.0 \mathrm{mg}$ of Dutasteride into a screw-capped centrifuge tube and $10 \mathrm{ml}$ of water added. Heated at $40^{\circ} \mathrm{C}$ for 10 minutes and shake for 20 minutes. To the solution, $8 \mathrm{ml}$ diluent was added and shake well. $2 \mathrm{ml}$ of internal standard stock solution added and shake well, centrifuged at $3000 \mathrm{rpm}$ for 10 minutes and used the supernatant passed through $0.45 \mu$ PVDF membrane filter.

\section{System Suitability Studies}

\section{RESULTS AND DISCUSSION}

System suitability testing is an integral part of the analytical procedure, the parameters like resolution, tailing factor, theoretical plates and area \%RSD are determined for a standard solution. (Fig.-1) The results are tabulated in Table-1.

Table-1: System Suitability Results

\begin{tabular}{c|c|c|c|c}
\hline Parameters & Tamsulosin $\mathrm{HCl}$ & Internal Standard & Dutasteride & Limit \\
\hline Retention time & 2.804 & 4.371 & 12.914 & -- \\
\hline Resolution ( R ) & - & 11.306 & 29.758 & $\mathrm{R}>2$ \\
\hline Tailing factor (T) & 1.31 & 1.16 & 0.98 & $\mathrm{~T}<2$ \\
\hline Theoretical plates (N) & 7365 & 14083 & 14544 & $\mathrm{~N}>2000$ \\
\hline Area \%RSD & 0.07 & 0.08 & 0.07 & $<2.0$ for $\mathrm{n} \geq 5$ \\
\hline
\end{tabular}


RASĀYAN J. Chem.

Vol. 14 | No. 2 |665-671| April - June | 2021

\section{Specificity}

Specificity is the ability to assess unequivocally the analyte in the presence of components that may be expected to be present and to provide an exact content or potency of the analyte in the sample. The test solution monitored on PDA (Fig.-2).

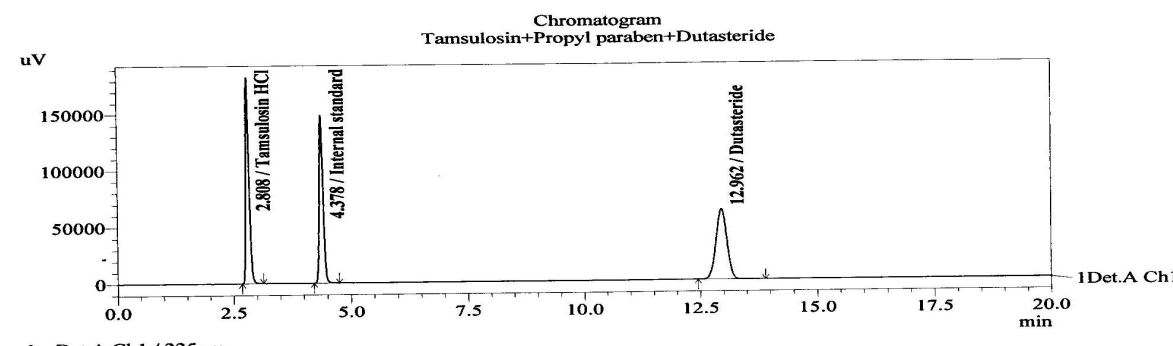

1 Det.A Ch1 / 225nm

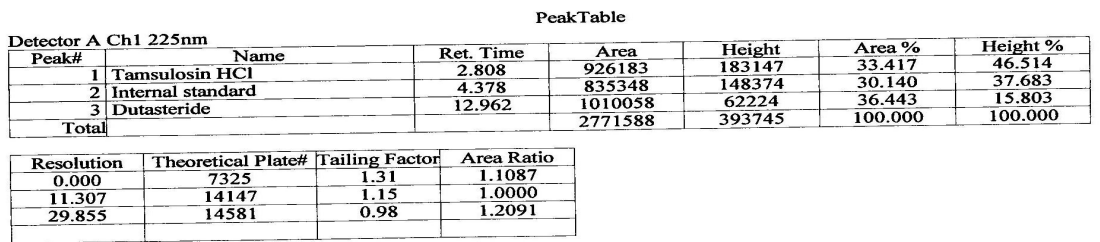

Fig.-1: System Suitability Chromatogram

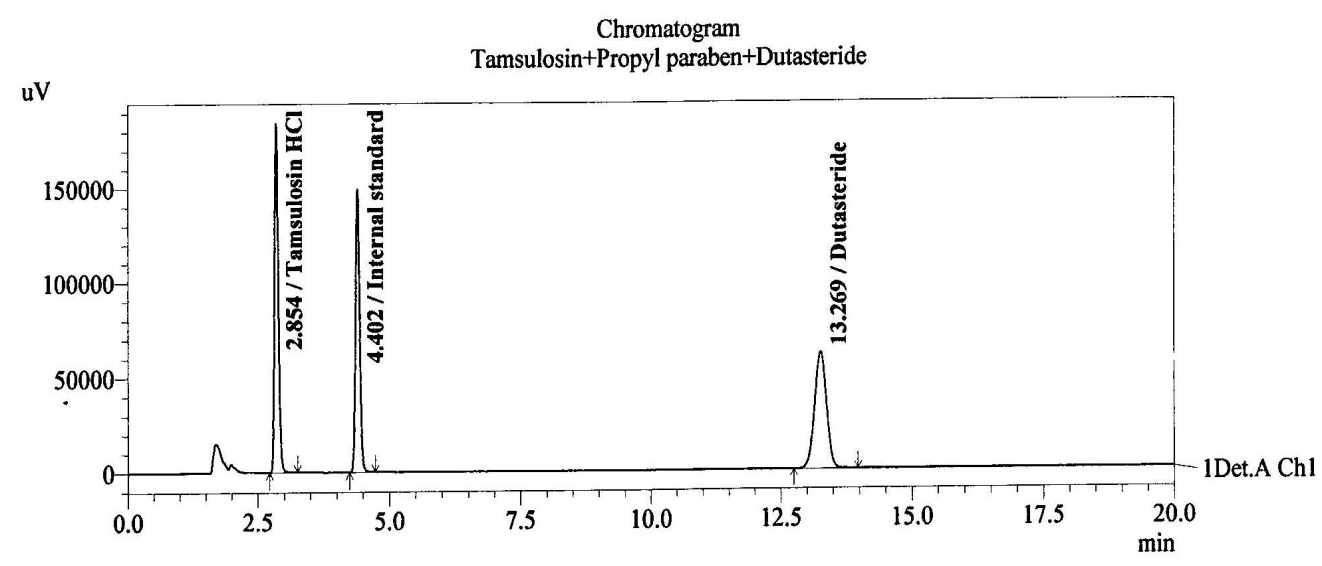

1 Det.A Ch1 / 225nm

\section{Accuracy}

Fig.-2: Test Chromatogram

The accuracy of an analytical procedure expresses the closeness of agreement between the value which is accepted either as a conventional true value or an accepted reference value and the value found. The method accuracy was determined based on recovery experiments. The recovery studies were carried out at three concentration levels with triplicate preparations. The percentage recovery mean recovery and standard deviation of the percentage recovery were calculated. (Table-2 and 3).

Table-2: Tamsulosin HCl Accuracy Results

\begin{tabular}{|c|c|c|c|c|c|}
\hline Spiked Level & $\begin{array}{l}\text { Sample Amount Added } \\
(\mathrm{mcg} / \mathrm{ml})\end{array}$ & $\begin{array}{l}\text { Sample Amount Recovered } \\
(\mathrm{mcg} / \mathrm{ml})\end{array}$ & $\begin{array}{c}\% \\
\text { Recovery }\end{array}$ & $\begin{array}{l}\text { Mean \% } \\
\text { Recovery }\end{array}$ & $\%$ RSD \\
\hline $50 \%$ & 19.9010 & 20.2731 & 101.87 & \multirow{3}{*}{100.93} & \multirow{3}{*}{1.0} \\
\hline $50 \%$ & 20.0990 & 20.3121 & 101.06 & & \\
\hline $50 \%$ & 20.0792 & 20.0511 & 99.86 & & \\
\hline $100 \%$ & 40.3960 & 40.4082 & 100.03 & \multirow{3}{*}{100.17} & \multirow{3}{*}{0.19} \\
\hline $100 \%$ & 40.4950 & 40.5274 & 100.08 & & \\
\hline $100 \%$ & 40.1980 & 40.3548 & 100.39 & & \\
\hline
\end{tabular}

667 
RASĀYAN J. Chem.

Vol. 14 | No. 2 |665-671| April - June | 2021

\begin{tabular}{c|c|c|c|c|c}
\hline $150 \%$ & 60.4950 & 60.1684 & 99.46 & \multirow{2}{*}{100.35} & \multirow{2}{*}{1.62} \\
\cline { 1 - 4 } $150 \%$ & 60.3960 & 60.0095 & 99.36 & & \\
\hline $150 \%$ & 58.7129 & 60.0163 & 102.22 & & \\
\hline
\end{tabular}

Table-3: Dutasteride Accuracy Results

\begin{tabular}{|c|c|c|c|c|c|}
\hline Spiked Level & $\begin{array}{l}\text { Sample Amount Added } \\
(\mathrm{mcg} / \mathrm{ml})\end{array}$ & $\begin{array}{l}\text { Sample Amount Recovered } \\
(\mathrm{mcg} / \mathrm{ml})\end{array}$ & $\begin{array}{c}\% \\
\text { Recovery } \\
\end{array}$ & $\begin{array}{l}\text { Mean \% } \\
\text { Recovery }\end{array}$ & $\%$ RSD \\
\hline $50 \%$ & 24.8762 & 24.7842 & 99.63 & \multirow{3}{*}{98.95} & \multirow{3}{*}{0.78} \\
\hline $50 \%$ & 25.1238 & 24.6489 & 98.11 & & \\
\hline $50 \%$ & 25.0990 & 24.8756 & 99.11 & & \\
\hline $100 \%$ & 50.4950 & 50.1012 & 99.22 & \multirow{3}{*}{100.12} & \multirow{3}{*}{0.91} \\
\hline $100 \%$ & 50.6188 & 50.6694 & 100.1 & & \\
\hline $100 \%$ & 50.2475 & 50.7701 & 101.04 & & \\
\hline $150 \%$ & 75.6188 & 76.6850 & 101.41 & \multirow{3}{*}{100.16} & \multirow{3}{*}{1.87} \\
\hline $150 \%$ & 75.4950 & 76.2953 & 101.06 & & \\
\hline $150 \%$ & 73.3911 & 71.9233 & 98.00 & & \\
\hline
\end{tabular}

Precision

The precision of an analytical procedure expresses the closeness of agreement (degree of scattering) between a series of measurements obtained from multiple sampling of the same homogeneous sample under the prescribed conditions. The \% assay calculated for six different preparations of the sample (Fig.3 and Table-4).

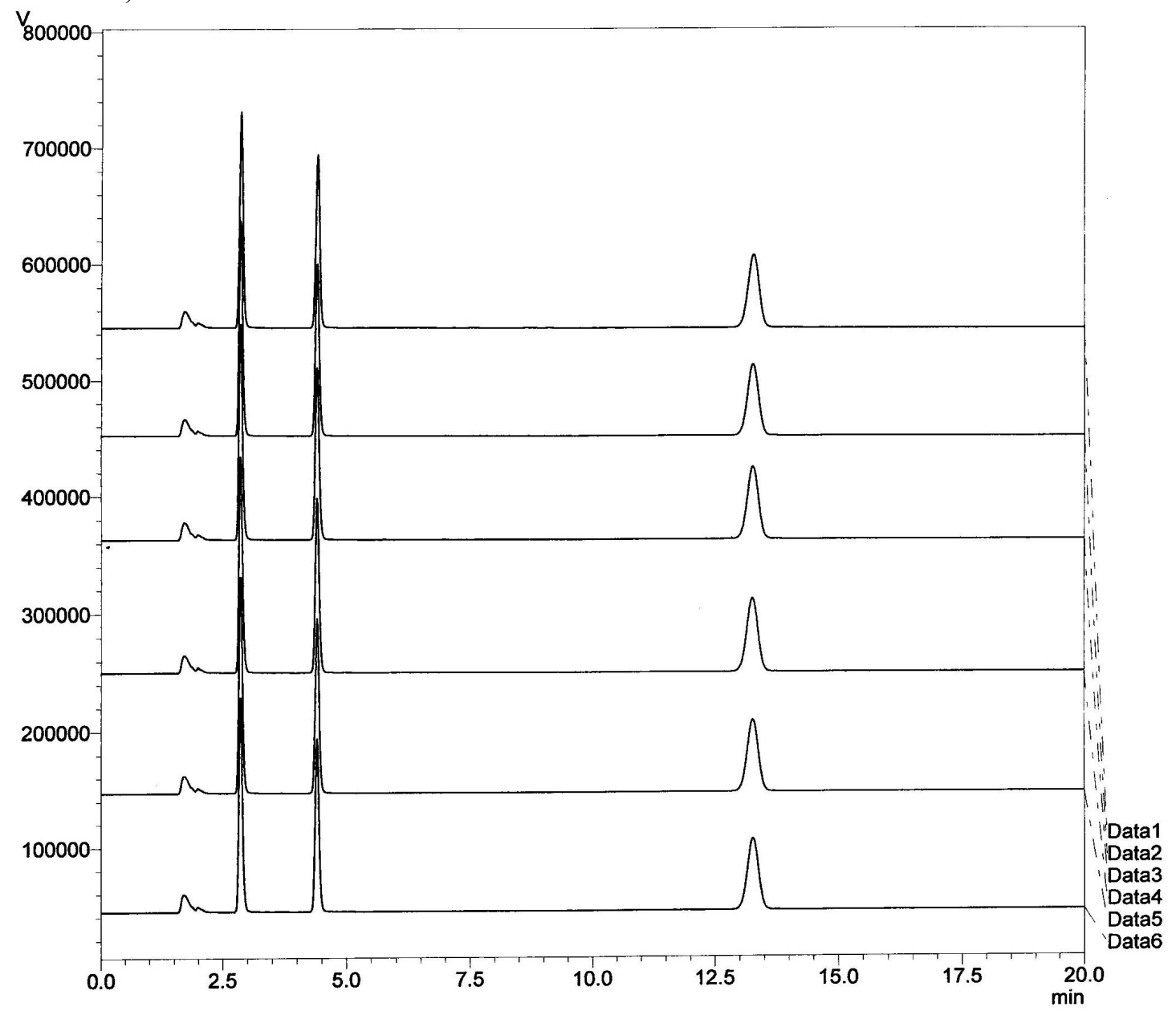

Fig.-3: Overlay Precision Chromatogram 
RASĀYAN J. Chem.

Vol. 14 | No. 2 |665-671| April - June | 2021

Table-4: Precision Results

\begin{tabular}{c|c|c}
\hline S. No. & $\begin{array}{c}\text { \% Assay } \\
\text { (Tamsulosin HCl) }\end{array}$ & $\begin{array}{c}\text { \% Assay } \\
\text { (Dutasteride) }\end{array}$ \\
\hline Preparation-1 & 100.03 & 99.22 \\
\hline Preparation-2 & 100.08 & 100.10 \\
\hline Preparation-3 & 100.39 & 101.04 \\
\hline Preparation-4 & 101.34 & 99.97 \\
\hline Preparation-5 & 101.30 & 99.84 \\
\hline Preparation-6 & 101.39 & 100.28 \\
\hline Average Assay: & 100.75 & 100.08 \\
\hline Std. Deviation & 0.66 & 0.59 \\
\hline \%RSD & 0.65 & 0.59
\end{tabular}

\section{Linearity Range}

The analytical procedure linearity is its ability (within a given range) to obtain test results. The results are directly proportional to the concentration (amount) of an analyte in the sample. The interval between the upper and lower concentration (amounts) of analyte in the sample (including these concentrations) has been demonstrated that the range of analytical procedure which has a suitable level of precision, accuracy and linearity.

Linearity was determined by plotting ratio's of the peak areas for Tamsulosin $\mathrm{HCl}$, Dutasteride and the internal standard against the concentration of solutions. The linearity of Tamsulosun $\mathrm{HCl}$ and Dutasteride determined in the concentration ranges of $40.00-60.00 \mu \mathrm{g} / \mathrm{mL}$ and $25-75 \mu \mathrm{g} / \mathrm{mL}$ respectively. The Tamsulosin $\mathrm{HCl}$ regression equation is $\mathrm{y}=0.027 \mathrm{x}$ with a coefficient of correlation $\left(\mathrm{R}^{2}\right)$ of 0.999 . The Dutasteride regression equation is $\mathrm{y}=0.024 \mathrm{x}-0.010$ with a coefficient of correlation $\left(\mathrm{R}^{2}\right)$ of 0.999 and shown in Figs.-4 and 5 and the overlay linearity chromatograms shown in Fig.- 6 . The range of the analytical method determined for Tamsulosin $\mathrm{HCl}$ and Dutasteride (Table-5).

Table-5: Range Results

\begin{tabular}{c|c|c|c}
\hline Parameter & Unit & Tamsulosin $\mathrm{HCl}$ & Dutasteride \\
\hline Range & $\mathrm{mcg} / \mathrm{mL}$ & $20.00-60.00$ & $25.00-75.00$ \\
\hline Linearity & Correlation coefficient $\left(\mathrm{r}^{2}\right)$ & 0.999 & 0.999 \\
\hline Accuracy at $50 \%$ & \% recovery & 100.93 & 98.95 \\
\hline Accuracy at $150 \%$ & \% recovery & 100.35 & 100.16 \\
\hline Precision at $50 \%$ & \% RSD & 1.00 & 0.78 \\
\hline Precision at $150 \%$ & \% RSD & 1.62 & 1.87 \\
\hline
\end{tabular}

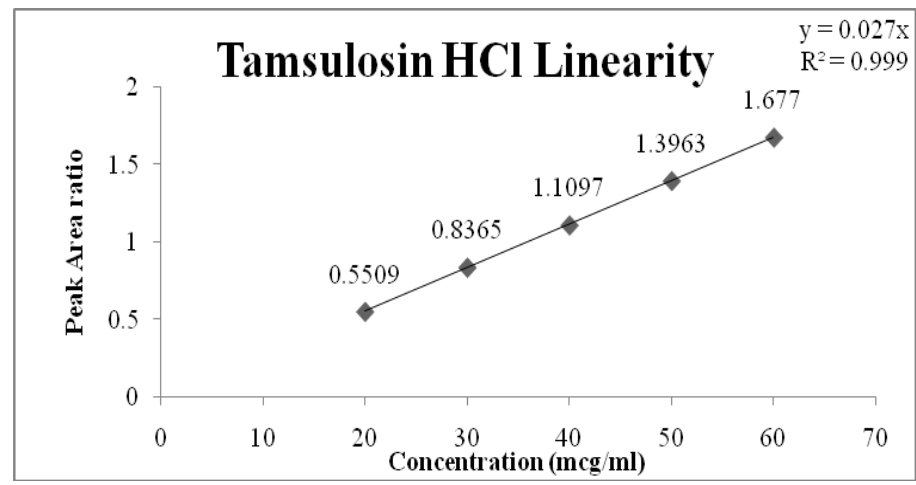

Fig.-4: Tamsulosin $\mathrm{HCl}$ Calibration Curve

\section{Robustness and Ruggedness}

The analytical procedure robustness is small, but deliberate variations in method parameters measurement. The capacity of the method to remain unaffected and indicates its reliability when compared to normal usage.

Robustness was determined a change in the flow rate $\pm 0.1 \mathrm{ml} /$ minute, column oven $\pm 5^{\circ} \mathrm{C}$, organic phase in mobile phase $\pm 5 \%$ and different batch of the column with the different analyst. 
RASĀYAN J. Chem.

Vol. 14 | No. 2 |665-671| April - June | 2021

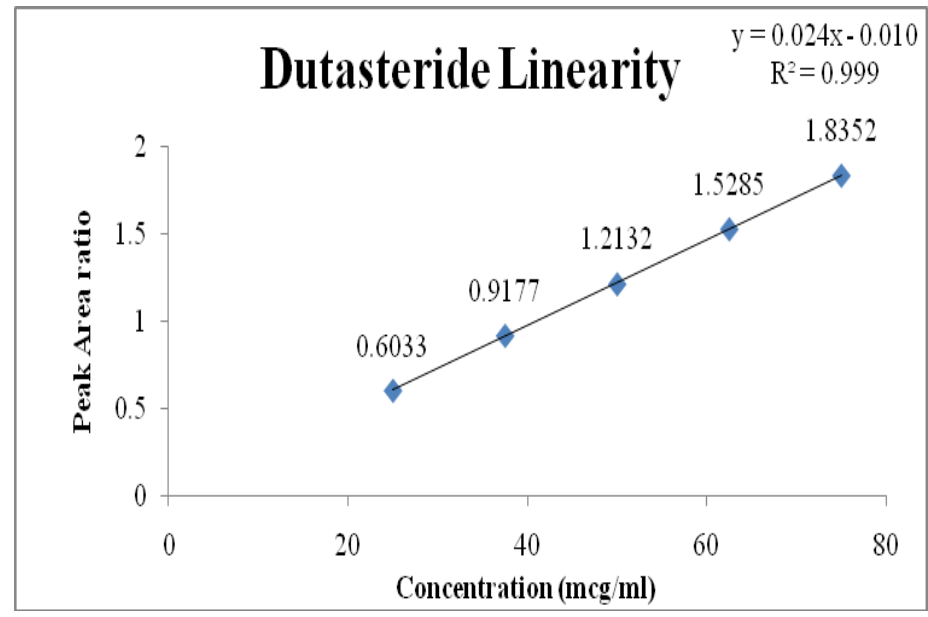

Fig.-5: Dutasteride Calibration Curve

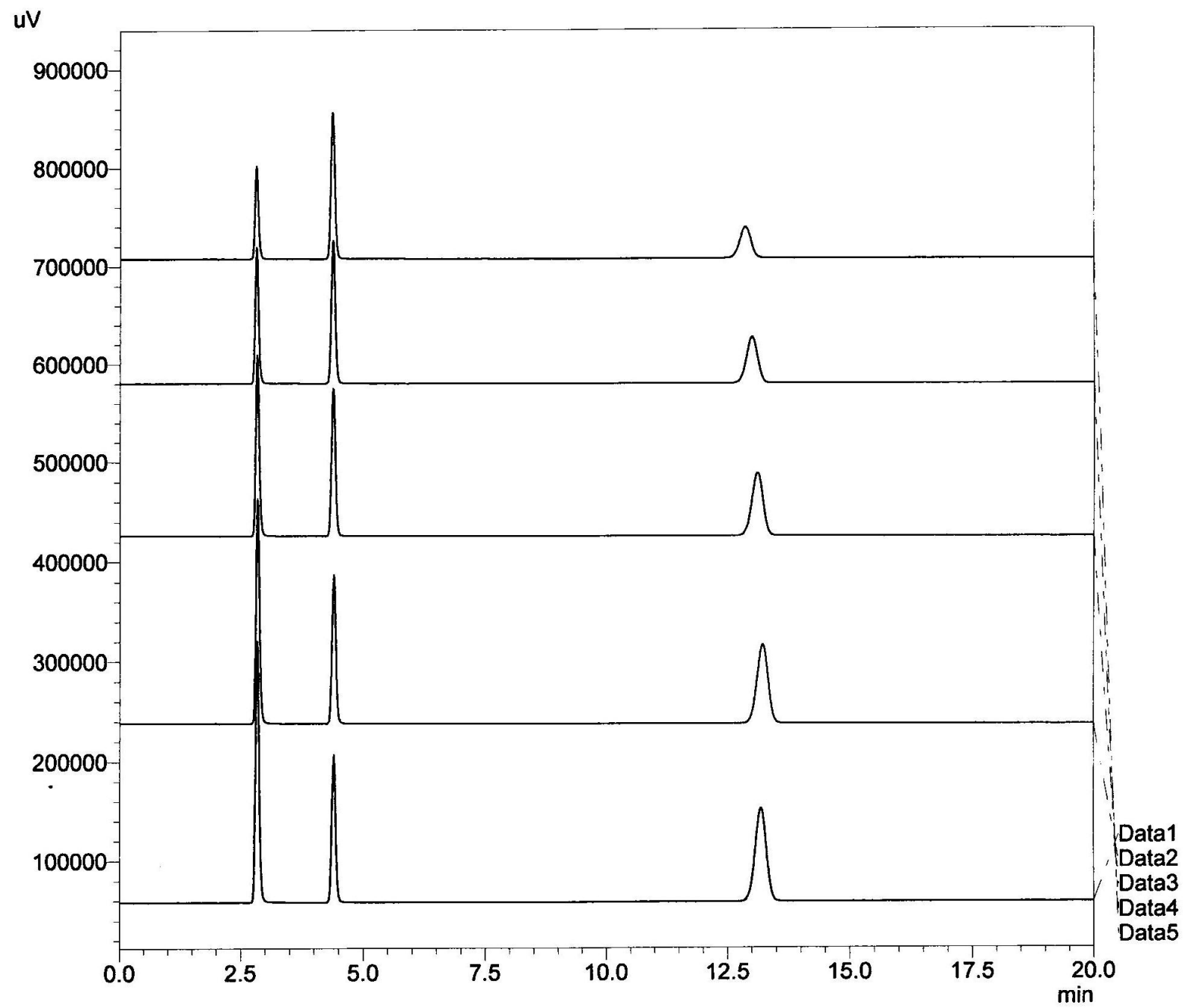

Fig.-6: Overlay Linearity Chromatogram

System suitability results were given in Table-1 and system suitability parameters are retention time, resolution, tailing, resolution, and plate count were within the acceptable limits. So, the system is suitable for the analysis. The test chromatogram extracted on PDA detector the peak Tamsulosin $\mathrm{HCl}$ and TAMSULOSIN HCl AND DUTASTERIDE IN TABLETS 670 
RASĀYAN J. Chem.

Vol. 14 | No. 2 |665-671| April - June | 2021

Dutasteride purities found 1.0 respectively indicates no interference, so the method is specific. Tamsulosin $\mathrm{HCl}$ recovery was found 100.17 to $100.93 \%$ and \%RSD was 0.19 to 1.62 , Dutasteride recovery was found 98.95 to $100.16 \%$ and $\% \mathrm{RSD}$ was 0.78 to 1.87 indicates the method is accurate 50 to $150 \%$ of the target concentration. Six different \%assay preparation values of the same homogeneous samples found 100.03 to $101.39 \%$ for Tamsulosin $\mathrm{HCl}$ and 99.22 to $101.04 \%$ for Dutasteride indicates the method is precise. Tamsulosin $\mathrm{HCl}$ Linear correlation was found to be $\mathrm{y}=0.027 \mathrm{x}$, the correlation coefficient was 0.999 and Dutasteride was $\mathrm{y}=0.024 \mathrm{x}-0.010$ and correlation coefficient was 0.999 indicates the method is linear across the target concentration. The method unaffected due to deliberate changes in flow rate, column oven temperature and different batch columns with different analysts proves the method is robust and rugged. The LOD and LOQ values were found to be 0.13 and $0.4 \mathrm{mcg} / \mathrm{mL}$ for Tamsulosin $\mathrm{HCl}$ and 0.17 and $0.5 \mathrm{mcg} / \mathrm{mL}$ for Dutasteride respectively. The proposed range 50 to $150 \%$ of the target concentration i.e., 20.00 to $60.00 \mathrm{mcg} / \mathrm{mL}$ for Tamsulosin $\mathrm{HCl}$ and 25.00 to $75.00 \mathrm{mcg} / \mathrm{mL}$ for Dutasteride found linear, accurate and precise (Table-5).

\section{CONCLUSION}

A new, specific, selective, linear, accurate and precise isocratic RP-HPLC ratio's method was developed for the estimation of Tamsulosin $\mathrm{HCl}$ and Dutasteride in their pharmaceutical tablet formulation. The proposed method was successfully separated Tamsulosin $\mathrm{HCl}$, Dutasteride and internal standard. The Proposed method is specific, selective, and stability-indicating power. Hence the developed method could be adapted to regular quality control analysis and stability analysis.

\section{ACKNOWLEDGEMENT}

The authors are thankful to the Department of Science \& Humanities, M/s Bharat Institute of Higher education and research, Chennai India for encouragement.

\section{REFERENCES}

1. Indian Pharmacopoeia, Indian Pharmacopoeia Commission, Ghaziabad, p.1633,2824(2014).

2. United States of Pharmacopoeia and National Formulary, The United States Pharmacopeial Convention, Rockville, p.1535,4169(2019).

3. European Pharmacopoeia, European Directorate for the Quality of Medicines \& HealthCare, Council of Europe, France, p.2118,3364(2014).

4. G. Sravan Kumar Reddy, S. Ashutosh Kumar, Manidipa Debnath, Viriyala Raj Kumar, International Journal of Pharmacy and Pharmaceutical Sciences, 6, 77 (2014).

5. B. Mohammed Ishaq, K. Vanitha Prakash and G. Krishna Mohan, Der Pharma Chemica, 6, 103 (2014).

6. Dendukuri V. L. N. Mrudula, G. Sai Prasad, P. V. Rao, S. Manohar Babu, International Journal of Research in Pharmaceutical and Nano Sciences, 3, 242 (2014).

7. L. Shivakumar Reddy, S.L.N. Prasad Reddy And G.Srinivas Reddy, Oriental Journal of Chemistry, 29, 1665 (2013), DOI: $10.13005 /$ ojc/290456

8. Y. Sowmya, P. Aleti, R. K. Venisetty, International Journal of Pharmacy and Biological Sciences, 3, $301(2013)$.

9. P. Giriraj, T. Siva K. Kumar, International Journal of Drug Development and Research, 6, 36 (2014).

10. Jahnavi Bandla, Gorja Ashok, World Journal of Pharmaceutical Research, 3, 4113 (2014).

11. V. Mohan Goud, A. Srinivasa Rao, S. V. Phanindra, S. Pragati Ranjan, K. Praveen Reddy, Asian Jounal of Pharmaceutical and Clinical Reseach, 2, 570 (2014).

12. P. Nagaraju, B. Durga Prasad, G. Indira Priyadarshini, Advance Pharmaceutical Journal, 2, 134 (2017).

13. ICH Q2 (R1), Validation of Analytical Procedure: Text and Methodology, November 2005.

[RJC-5740/2020] 